\title{
Memaknai 1 Timotius 4:12-16 Sebagai Dasar Pak Perguruan Tinggi Umum
}

\author{
Bintahan Marodjahan Harianja \\ Radio Bonafit HKBP FM Tarutung
}

\begin{abstract}
Abstrak
Artikel ini adalah suatu upaya untuk mendapatkan corak Pendidikan Agama Kristen di Perguruan Tinggi Umum yang berwawasan pluralis. Seyogianyalah Pendidikan Agama Kristen di Indonesia harus berakar dan hidup di tengah-tengah konteks masyarakat Indonesia yang majemuk, dan harus mampu mengkomunikasikan firman Tuhan sesuai dengan lingkup keindonesiaan yang pluralis. Tulisan ini berangkat dari pergumulan mengenai arah pendidikan keagamaan yang semakin eksklusif atau tertutup pada waktu belakangan ini, dan tentunya bukan itu yang dibutuhkan oleh Indonesia. Salah satu upaya yang dapat dilakukan adalah menginterpretasi ulang teks-teks suci yang dapat menjadi dasar pendidikan agama yang berwawasan pluralis, dalam hal ini adalah teks 1 Timotius 4:12-16. Teks ini muncul dalam masyarakat Efesus yang plural tempat pemimpin gereja bernama Timotius melayani. Interpretasi yang kritis menghasilkan pesan bahwa Paulus menginginkan Timoteus untuk mampu mendialogkan Injil tanpa harus menghindari perbedaan yang menjadi ciri khas kota Efesus. Pengajaran Kristen harus mampu menyadarkan setiap peserta didik bahwa mereka adalah bagian dari kebhinekaan tersebut. Katakunci : Pendidikan Agama Kristen, Perguruan Tinggi Umum, 1 Timotius 4:12-16
\end{abstract}

\begin{abstract}
This article is an attempt to get a style of Christian Religious Education in Public Colleges with pluralist insights. Christian Christian Education in Indonesia should be rooted and live in the context of a pluralistic Indonesian society, and must be able to communicate the word of God in accordance with the pluralistic scope of Indonesian-ness. This paper departs from the struggle over the direction of religious education which has become increasingly exclusive or closed in recent times, and that is certainly not what is needed by Indonesia. One effort that can be done is to reinterpret sacred texts which can be the basis of religious education with a pluralist perspective, in this case the text of 1 Timothy 4: 1216. This text appears in the plural Ephesus community where the church leader named Timothy ministered. Critical interpretation produced the message that Paul wanted Timothy to be able to dialogue the Gospel without having to avoid the differences that were characteristic of the city of Ephesus. Christian teaching must be able to make every student aware that they are part of the diversity.
\end{abstract}

Keywords: Christian Religious Education, General Higher Education, Pluralism, 1

Timothy 4: 12-16

\section{PENDAHULUAN}

Di era postmodern dewasa ini pilihan model pengajaran (metode, substansi) yang bernafaskan sektarian, formalisasi, ataupun primordialis mulai tersisihkan. Pilihan pola pengajaran yang lebih bermartabat itu bukan hanya dikembangkan di negara-negara maju seperti di benua Amerika ataupun Eropa tetapi juga di belahan dunia kedua dan ketiga, termasuk Indonesia. Tulisan ini secara khusus menyoroti pengajaran Pendidikan Agama Kristen (PAK) yang menjadi salah satu bagian

84 | Korespondensi mengenai artikel dapat dilakukan kepada: Bintahan Marodjahan Harianja, I Radio Bonafit HKBP FM Tarutung, Jl. Raya Tarutung-Siborong KM 11, Silangkitang, Sipoholon, Tapanuli Utara (22452), Indonesia e-mail Corresponding: binbinemail@yahoo.com 
penting dalam Sistem Pendidikan Nasional. Tujuan usaha pendidikan di setiap tahapan formal adalah bagian tujuan usaha pendidikan nasional, hal ini juga berlaku bagi kegiatan PAK.

Keniscayaan keanekaragaman dalam kehidupan berbangsa dan bernegara telah menjadi suatu konfesi bersama dalam semboyan Bhineka Tunggal Ika. Para pendiri bangsa ini sangat menyadari hal tersebut dan harus tetap menjadi akar berpijak bagi generasi selanjutnya sehingga semangat pluralisme tetap menjadi "nafas" dari setiap langkah dan gerak bersama, tidak terkecuali bagi Sistem Pendidikan Nasional. Dalam tujuan Sistem Pendidikan Nasional terdapat pengendalian diri serta spiritual keagamaan, hal ini mengindikasikan bahwa pendidikan agama harusnya mengajarkan naradidik tentang pluralisme agama agar mampu mengendalikan siswa agar menjadi baik, arif, bijaksana dalam beragama bukan bertujuan mendidik naradidik menjadi fundamental dalam beragama.

Bahasan ini adalah menjadi penting dalam perjalanan bangsa Indonesia, terkhususnya pada beberapa dekade belakangan ini dimana di sana-sini muncul paham dan gerakan radikalisme keagamaan yang mencoba-coba mengancam kesatuan dan persatuan bangsa. Tentu saja ada banyak faktor yang melahirkan semangat radikalisme yang terjadi di berbagai belahan nusantara, tetapi pola dan substansi pendidikan keagamaan yang menurut hemat kami sangat dogmatis dan eksklusif tentu memainkan peranan penting serta menjadi persemaian yang baik bagi bibit radikalisme (yang tampaknya memang sengaja ditanamkan). Di lain pihak, di kalangan dunia akademis yang banyak bergelut dalam pengembangan sistem PAK di Indonesia tentunya harus selalu juga diingatkan bahwa ancaman ekslusivisme (atau radikalisme?) tidaklah begitu jauh-jauh juga berkutat dari lingkungan mereka. Hal ini terbukti dari beberapa konflik horizontal yang dikaitkaitkan dengan isu agamais, ataupun munculnya beberapa kebijakan-kebijakan Pemerintah Daerah yang tampaknya sangat mengakomodir kepentingan umat Kristiani (misalnya Perda Injili di Papua) secara tak sadar telah merugikan semangat kepluralismean bangsa, dan tentunya kita tidak bisa menafikan bahwa ini merupakan salah satu buah dari PAK yang dikembangkan dalam dunia formal di dua-tiga generasi terakhir.

Fakta yang sederhana di atas mengerucutkan kita pada kesadaran bahwa ternyata masih ada pekerjaan rumah yang harus kita selesaikan dalam corak PAK yang seharusnya kita tumbuhkembangkan. Perguruan Tinggi Umum (PTU) adalah bagian akhir dari seluruh jenjang pendidikan formal, dengan segala keterbatasannya namun tahapan ini diyakini memiliki peranan yang penting dalam pembentukan pola pikir generasi bangsa yang dilahirkannya. Sehingga dengan demikian perlu sekali merumuskan dengan nyata corak atau model PAK yang seperti apakah yang dibutuhkan di PTU yang bermanfaat bagi bangsa, negara dan masyarakat majemuk, khususnya bhineka keagamaan. 
JURNAL CHRISTIAN HUMANIORA

Vol.4, No.1, May 2020, pp. 72-92

p-ISSN: 2598-6317- e-ISSN: 2599-196

\section{Pluralisme Agama dalam PAK di PTU dan Signifikansinya}

\section{Tempat PAK dalam konteks keindonesiaan}

Seperti yang kita ketahui, ada perbedaan yang mendasar antara pendirian masing-masing negara terhadap soal hubungan antara pendidikan umum dan agama, tidaklah seragam. Setidaknya kita dapat membaginya menjadi 5 model pengimplementasian PAK atau pendidikan keagamaan di dunia formal, yaitu: negara yang melarang sama sekali melarang pendidikan agama di sekolah umum, negara yang toleran dengan pendidikan agama walaupun pemerintah tidak mementingkan agama, negara yang memberi hak kepada gereja untuk penyelenggaraan PAK, negara yang menceraikan agama dan pendidikan umum, serta negara yang mengizinkan pendidikan agama di sekolah negeri yang seluruhnya dibiayai oleh negara.

Indonesia sendiri mengadopsi model yang disebutkan terakhir dimana tenaga pendidik di dunia pendidikan formal dari agama apapun itu yang memberikan pelajaran agama semuanya dibayar oleh negara sendiri. Faedah dan bahaya model pendidikan seperti ini tampaknya sangatlah berimbang. Homrighausen melihat beberapa keuntungan model ini: bagi gereja dapat menyampaikan Injil kepada anak Kristen yang sukar dikumpulkan dalam PAK gereja sendiri, membantu gereja dalam segi pendanaan pengajaran yang seharusnya tanggung jawab gereja itu sendiri, PAK di lingkungan pendidikan umum membuat naradidik merasakan keterhubungan pendidikan spritualitas dengan intelektualitas, dan menjadikan agama sebagai budaya bersama. Di pihak lain kita tidak boleh menutup mata atas bahayanya: formalisasi keagamaan, hilangnya keunikan PAK sebagai penuntun iman pribadi, berkurangnya peran gereja, dan intervensi negara terhadap kurikulum dan inti pengajaran.

Baiklah selanjutnya nanti kita melihat lebih banyak dari sisi positipnya saja yang nantinya memacu kita untuk mencari upaya yang dapat meminimalisasi efek negatif "kemudahankemudahan" yang diberikan negara bagi PAK di pendidikan formal di Indonesia. Peluang tersebut harus benar-benar disikapi dengan bijaksana oleh gereja yang seharusnya bertanggungjawab penuh terhadap proses dan keberlangsungan PAK di Sekolah di Indonesia.

\section{Tantangan PAK di PTU dalam konteks Indonesia yang Pluralis}

Tidak dapat dimungkiri, di dekade belakangan ini ada kecurigaan umum bahwa pendidikan agama kurang mendapat tempat dan kurang berkembang di dalam usaha kependidikan formal, tidak terkecuali di Perguruan Tinggi Umum dan khususnya Pendidikan Agama Kristen. Hal ini seharusnya tidak boleh dibiarkan berlarut-larut hadir dalam sistem pendidikan nasional, karena benang merahnya akan mengarah kepada karakteristik generasi bangsa yang miskin sisi spiritualitas.

Secara umum rumusan tujuan PAK di PTU adalah membentuk mahasiswa dan membantu terbinanya sarjana beragama, dan bertaqwa kepada Tuhan yang Maha Esa, berbudi pekerti luhur, berfikir filosofis, bersikap rasional dan dinamis, berpandangan luas, ikut seta dalam kerjasama antar 
umat beragama dalam pengembangan dan pemanfaatan ilmu pengetahuan dan teknologi untuk kepentingan nasional. Beberapa hal yang disinggung dalam rumusan di atas menunjukkan bahwa terkandung nilai-nilai luhur yang dapat diupayakan secara bersama-sama demi suatu tujuan yang lebih besar yaitu tujuan berbangsa dan bernegara.

Dalam kenyataannya, seperti yang telah kita singgung di atas, di beberapa belahan bagian nusantara akhir-akhir ini muncul gerakan radikalisme keagaaman yang tidak hanya didominasi oleh satu label agama tertentu, tidak terkecuali Kristen. Menurut hemat kami, persoalan ini muncul dari kealpaan kita terhadap tugas penting dari konteks. Sebagaimana yang kita ketahui bahwa teori pendidikan yang baik seharusnya juga dibentuk oleh konteks masyarakat, sehingga dengan begitu PAK yang kita selenggarakan haruslah selalu dipetakan menurut konteks di mana ia dilaksanakan sehingga melahirkan praktik hidup yang benar. Dalam kerangka kerja ini, membuat suatu rencana pendidikan dimulai dengan menggambarkan konteks atau persoalan komunitas, yaitu komunitas yang bagi merekalah teori PAK ini direncanakan. Konkritnya, signifikansi model pendekatan dengan dimulai dari konteks, maka PAK akan mengarah sambil menghadapi masalah dan kebutuhan masyarakat yang baginya teori dan proses pengajaran itu dibuat.

Dalam konteks kebangsaan, kebhinekaan tentunya adalah sebuah keniscayaan. Dia bukanlah suatu bahan perbincangan yang baru begitu saja muncul namun merupakan eksistensi bangsa, dengan kesadaran penuh para pendiri bangsa ini sejak awalnya telah menyatakannya dengan lantang bahwa perbedaan itu sebagai semboyan negeri Indonesia. Bhineka dalam budaya dan bhineka dalam kepercayaan. Di masyarakat dijumpai penganut agama Baha'i, Tao, Sikh, Yahudi, Kristen Ortodoks, bahkan juga agama-agama perenial, yaitu agama yang tidak mengambil bentuk formal, tetapi lebih mengutamakan penghayatan akan kehadiran Tuhan dan implementasi nilainilai agama. Selain itu, juga dikenal ratusan kepercayaan lokal (indigenous religions), seperti Parmalim di Sumatera Utara, Kaharingan di Kalimantan, Sapto Darmo di Jawa Tengah, Sunda Wiwitan di Kuningan, Jawa Barat, dan Tolotang di Sulawesi Selatan. Jika mengacu data Kementerian Budaya dan Pariwisata 2018, setidaknya tercatat ada 248 organisasi aliran kepercayaan dengan jumlah penganut sebesar 8.821 .724 jiwa, belum lagi yang sifatnya pribadi dan lokal. Wajar saja, mengingat data Badan Pusat Statistik juga menyebut bangsa yang mendiami sekitar 13.466 pulau ini punya lebih dari 1.128 ragam etnis dengan sejarah spiritual masingmasing. Bicara tentang agama hakikatnya ialah bicara tentang interpretasi agama, faktanya tidak ada interpretasi tunggal dalam agama dan kepercayaan mana pun.

Berdasarkan pemahaman tersebut, baiklah kita melihat kemungkinan-kemungkinan nyata yang ada dalam pengimplementasian tujuan Pendidikan Agama Kristen di Perguruan Tinggi Umum di Indonesia. Yang pertama adalah dalam bentuk Kurikulum PAK yang membuatnya menjadi salah satu dari sekian mata kuliah yang diajarkan. Dalam kerangka ini, PAK (Christian Education) 
JURNAL CHRISTIAN HUMANIORA

Vol.4, No.1, May 2020, pp. 72-92

p-ISSN: 2598-6317- e-ISSN: 2599-196

menjadi spesifik dan berbeda dengan Pendidikan Keagamaan (Religious Education), walaupun banyak juga pihak yang mendukung model yang disebutkan terakhir karena dianggap lebih memungkinkan bertumbuhnya sikap toleransi yang tinggi dari naradidik. Tentu saja hal ini sekaligus menjadi tantangan tersendiri bagi PAK dalam penyusunan kurikulum dan silabus perkuliahan yang mampu menjawab tantangan kepluralan bangsa dan mengelaborasinya menjadi sebuah kekuatan yang sesuai dengan tujuan sistem pendidikan nasional, meningkatkan kualitas manusia Indonesia. PAK diajarkan sebagai sebuah mata kuliah tetapi juga merupakan asuhan iman Kristen yang menumbuhkan dan mendewasakan iman.

Yang kedua, di lain pihak PAK di PTU juga harus selalu menyadari dan memosisikan dirinya sebagai bagian pendidikan keagamaan secara menyeluruh, sebagai salah satu mata kuliah pendidikan keagamaan bersama pendidikan agama lain yang diaturkan dalam sistem perundangundangan di Indonesia. Untuk inilah dalam wawasan global, Hope menekankan bahwa para pengajar PAK harus selalu mengingat bahwa mereka ada di antara banyak pendidik agama lain, dan walaupun tugas mereka terus berlanjut dengan "bahasa pertama" tentang pembentukan iman melalui PAK, mereka juga harus bergerak ke "bahasa kedua" melalui Pendidikan Agama yang berwawasan pluralisme.

\section{Interpretasi dan Refleksi Biblis 1 Timotius 4:12-16 atas Pendidikan Agama Kristen di Perguruan Tinggi Umum}

\section{Pluralistis Efesus dan Pendekatan Hermeneutik}

Sejarahnya, Paulus membawa Timotius dalam kunjungannya ke jemaat-jemaat di Asia Kecil. Selesai perkunjungannya ini Paulus meninggalkan Timotius di Efesus (1 Timotius 1:3) dengan tugas untuk melanjutkan pembinaan jemaat-jemaat di sana, terlebih menghadapi pengajar sesat yang dapat mengacaukan persekutuan. Paulus sendiri melanjutkan perjalanannya ke Makedonia untuk mengunjungi jemaat-jemaat di wilayah ini. Dari Makedonia itulah ia menuliskan Surat 1 Timotius kepada Timotius (tahun $63 \mathrm{M}$ ). Surat ini memberikan kesan, bahwa rasul Paulus sedang menyiapkan Timotius untuk mengambil-alih tugas dari padanya sebagai generasi penerus tradisi dan kekayaan gereja.

Kota Efesus sendiri adalah tanah datar yang subur dekat muara Sungai Cayster, kota yang sangat indah, kota perdagangan dan memiliki sebuah bandar besar penghubung dunia barat dan timur. Efesus adalah kota terbesar, paling banyak penduduknya, dan terkaya di Asia Kecil. Ibu kota sipil, dagang, dan agama, dari Asia, sebuah propinsi Romawi. Kota Efesus sangat pluralis, sebenarnya mula-mula adalah "koloni" Yunani yang artinya banyak orang Yunani perantauan berdiam, banyak orang datang ke sana dari banyak belahan bumi, bukan hanya untuk berdagang namun juga karena adanya kuil besar Artemis dan gedung sandiwara (amfiteater) terbesar di Asia Kecil. 
Pendekatan hermeneutis terhadap Surat-surat Pengembalaan - dalam hal ini 1 Timotius, mengalami perkembangan dan tentu saja dengan sukjektivitas masing-masing. Telah banyak model yang dipakai para hermeneus, misalnya Freudian, Marxis, Feminis, dan sebagainya membuat teksteks di dalam surat ini dapat "berbicara banyak" menjawab tantangan umat di sepanjang masa, yang terpenting adalah pesan moralnya yang abadi. Untuk tulisan ini, pemaparan singkat konteks surat di atas menunjukkan metode kritik kesejarahan menjadi acuan penafsiran dengan perspektif pluralisme modern. Pengupayaan ini dilakukan untuk menjawab tantangan pluralisme dalam konteks keindonesiaan.

\section{Interpretasi dan Refleksi Teologis}

Timotius sangat muda ketika menerima surat ini (mungkin 33 tahun), usia yang bagi seorang pembina jemaat pada zaman itu masih sangat muda. Tetapi kemudaan tidak menjadi penghalang sebagai pembina bila mampu menjadi teladan bagi orang percaya (ayat 12), dalam perkataan dan tingkah laku. Upaya yang harus dilakukan oleh Timotius ini bukanlah pekerjaan yang selesai dalam sehari, dia mengupayakan dengan terus-menerus dan kerja keras, perubahan yang dimulai dari diri sendiri. Sementara Paulus tidak hadir dan mengindari pengajar-pengajar sesat yang selalu mengancam dengan pengaruh mereka, Timotius harus mengutamakan tugas membaca Kitab Suci, tujuannya tentu untuk memerlengkapi diri untuk membangunan dan mengajar, dan melawan pengajar sesat (ayat 13).

Namun itu semua tidak cukup bila hanya sebatas demi kepentingan dan kegunaan dirinya sendiri atau salah satu pihak tertentu, namun supaya kemajuanmu nyata kepada "semua orang" (ayat 15). Pernyataan ini merujuk kepada kesaksian hidup yang berdampak kepada kesukaan dan kebaikan banyak orang, menembus sekat-sekat penghalang. Paulus berulangkali mengingatkan bahwa keselamatan yang dibawa Kristus dapat saja mengurung orang-orang percaya ke dalam kehidupan yang egois dan jatuh ke dalam penghakiman religius. Dengan demikian tujuan akhir adalah adanya kesinergian melalui dialog dan sikap hidup yang akan menciptakan gerakan transformasi demi kesejahteraan bersama. Sebenarnya jelas sekali bahwa jemaat di kota ini bukanlah orang Yahudi tetapi mayoritas Helenistik, tapi yang menariknya menurut Frances Young, Paulus selalu saja berupaya untuk memasukkan unsur dan tradisi keyahudian dengan agama Kristen (gereja) sebagai alat mediasinya. Hal ini dapat terterima dengan latar belakang Paulus dan teologinya, lebih dari pada itu ini adalah proses pengajaran yang dilaksanakan secara perlahan serta terencana sehingga melahirkan keterbukaan terhadap keberadaan yang lainnya.

Wawasan pengajaran dan pelayanan pluralisme tampak jelas pula pada ayat 16. Di satu sisi dikemukakan bahwa penguasaan diri dan pengajaran yang sehat baik bagi pertumbuhan keimanan Timotius pribadi. Namun di pihak lain, "bertekun akan menyelamatkan orang yang mendengar engkau", pengajaran yang benar juga berdampak luas bagi orang lain. Wismoady mencatat ada 
JURNAL CHRISTIAN HUMANIORA

Vol.4, No.1, May 2020, pp. 72-92

p-ISSN: 2598-6317- e-ISSN: 2599-196

beberapa daya tarik jemaat mula-mula yang membuatnya menjadi mampu mengubah bumi abadabad permulaan. Salah satu yang menarik adalah keinklusifan mereka dalam menerima keberadaan orang-orang lain dan kepelbedaan, memerlakukan perbuatan kasih bukan hanya kepada sesamanya saja sehingga menjadi contoh yang baik bagi semangat kesederajatan dalam kepluralan mereka. Kehidupan yang semacam ini menjadi sesuatu yang umum dan jamak dalam pengajaran-pengajaran Yesus dan rasul di gereja mula-mula yang membuat mereka dapat menggarami atau mengubah dunia di mana mereka hidup dan bergaul. Paulus dalam surat-surat (pseudo-) Paulus bahkan berulang-ulang mengemukakan gagasan pluralistik ini sebagai bagian misi Kristiani, tidak ada lagi Yahudi dan Yunani (Galatia 3:28), mereka yang "jauh" dibuat dekat oleh penebusan Kristus (Efesus 2:11ff). Wawasan pluralisme yang memang harus selalu diperdengarkan dan diperjuangkan.

Dengan demikian, semangat menjaga kekudusan yang ditekankan oleh Paulus kepada muridnya bernama Timotius dalam nas ini membuatnya harus selalu memikirkan konteks kepluralan dalam setiap pola dan tingkah hidup, pengajaran, dan kesaksian yang nantinya baik untuk kemajuan peradaban bersama.

\section{KESIMPULAN}

Tugas PAK menjadi pekerjaan dua rangkap, yang pertama tentu saja yaitu memerlengkapi para peserta didik dalam tradisi iman mereka sendiri, dan yang berikutnya adalah memungkinkan mereka untuk selalu terbuka kepada pihak yang berasal dari tradisi agama lain. Groome menyebutkan perlunya untuk selalu mengingatkan praktisi PAK (guru agama, dosen, dan lainnya), bahwa mereka bukanlah pemilik perusahaan atau lembaga namun agama mereka adalah salah satu ekspresi darinya, dan bahwa mereka berbagi suatu pencarian ikatan bersama semua pendidik agama dari komunitas agama yang lain.

PAK yang baik adalah membuat peserta didik terangsang untuk melihat kemungkinankemungkinan yang lebih luas, termasuk adanya kebenaran yang berbeda dari apa yang telah diyakininya. Penggunaan kekristenan sebagai alat mediasi Paulus terhadap tradisi keyahudian dalam masyarakat Helenistik adalah dasar yang membuat PAK harus mampu mendialogkan perbedaan yang ada dalam pengambilan kesimpulan. Hal ini menjadi wahana bagi peserta didik untuk dapat menjalin hubungan yang saling menghormati dengan orang-orang yang berbeda keyakinan atau identitas keagamaan. Pengajaran Agama sering memberikan penekanan tentang "kebenaran" yang bersifat mutlak, tertutup atau satu-satunya, sehingga menghasilkan sikap beragama yang tertutup dan eksklusif.

PAK yang kontekstual di Indonesia bersifat mendorong peserta didik untuk memberikan "pengaruh" yang bermanfaat bagi lingkungan mereka melalui "ke-khasan" perkataan dan tingkah 
laku. Pola ini menjauhkan peserta didik dari sikap menghakimi atas kepelbedaan yang ada. PAK melatih anak-anak dalam pengakaran dasar kekristenan yang berbuah dalam pola hidup dan tingkah laku mereka. Pola hidup ini dipupuk bukan hanya untuk kebaikannya atau komunitas kekristenan semata, tetapi harus menjadi kesaksian kebaikan bagi "orang lain." Semangat-semangat yang seperti inilah yang harus selalu ditumbuh-kembangkan dalam metode, kurikulum, dan pengajaran PAK untuk Indonesia yang damai sejahtera.

\section{DAFTAR PUSTAKA}

Antone, Hope S., Pendidikan Kristiani Kontekstual, (Jakarta: BPK Gunung Mulia, 2010)

Bellis, Alice Ogden, dan Joel S. Kaminsky (ed.), Jews, Christian, and The Theology of The Hebrew Scriptures, (Atlanta: Society of Biblical Literature, 2000).

Boehlke, Robert, Sejarah Perkembangan Pikiran dan Praktek Pendidikan Agama Kristen, (Jakarta: BPK-Gunung Mulia, 2003)

Budiman, R., Tafsiran Alkitab: 1 \& 2 Timotius dan Titus, (Jakarta: BPK Gunung Mulia, 2011)

Danim, Sudarwan, Pengantar Kependidikan Landasan, Teori, Dan 234 Metafora Pendidikan (Bandung: Alfabeta, 2011)

Drane, John, Memahami Perjanjian Baru, (Jakarta: BPK Gunung Mulia, 2006)

Dunn, James D.G., The Theology of Paul the Apostle, (Michigan: Grand Rapids, 1998)

Duyverman, M.E., Pembimbing ke dalam Perjanjian Baru, (Jakarta: BPK Gunung Mulia, 2011)

Groome, Thomas H., Christian Religious Education, (Jakarta: BPK Gunung Mulia, 2011)

Guthrie, Donald, Teologi Perjanjian Baru 3, (Jakarta: BPK Gunung Mulia, 2012)

Homrighausen, E.G. dan I.H.Enklaar, Pendidikan Agama Kristen, (Jakarta: BPK Gunung Mulia, 2008)

Ismail, Andar (ed.), Ajarlah Mereka Melakukan, (Jakarta: BPK Gunung Mulia, 2011)

John Arthur Thomas Robinson, Redating the New Testament, (Westminster Press, 1976)

Lefebure, Leo D., Penyataan Allah, Agama, dan Kekerasan, (Jakarta: BPK-Gunung Mulia, 2005)

Lemhanas, Pendidikan Kewiraan Untuk Mahasiswa. (Jakarta: Gramedia, 1988)

Lincoln, Andrew T., The Theology of The Later Pauline Letters, (Cambridge: Cambridge University Press 1993)

Mufid, Ahmad Syafi'i (ed.), Kasus-kasus Aktual Kehidupan Keagamaan di Indonesia, (Jakarta: Puslitbang Kementerian Agama RI, 2014)

Pangabean, Yusril, Pendidikan Agama Kristen, (Yogyakarta: UPT MKU UNY, 2003)

PGI, Strategi Pendidikan Kristen di Indonesia, (Jakarta: BPK Gunung Mulia, 1989)

Rampak, Nasarius, Buku Materi Pokok Pendidikan Agama Kristen. (Jakarta: Karunia Universitas Terbuka, 1985)

Sianturi, Harapan, "Hakikat Pendidikan Agama Kristen”, dalam: Jurnal Teologi Stulos Vol. 9, (STT Bandung) 


\section{JURNAL CHRISTIAN HUMANIORA}

Vol.4, No.1, May 2020, pp. 72-92

p-ISSN: 2598-6317- e-ISSN: 2599-196

Soden, H. Von, "New Testament chronology", dalam: Encyclopaedia Biblica, disunting oleh: T. K. Cheyne dan J. S. Black

Sugiharto, Bambang. Postmodernisme: Tantangan Bagi Filsafat, (Yogyakarta: Kanisius, 2002)

Wahono, Wismoady, Di Sini Kutemukan, (Jakarta: BPK Gunung Mulia, 2010)

Wahono, Wismoady (ed.), Pro-Eksistensi, (Jakarta: BPK Gunung Mulia, 2001)

Young, Frances, The Theology of the Pastoral Letters, (Cambridge University Press, 2004) 